http://nv.nltu.edu.ua

https://doi.org/10.15421/40290127

$@ \bowtie$ Correspondence author

Article received 29.01.2019 p.

R. L. Tkachuk

Article accepted 28.02.2019 p.

rlvtk@ukr.net

УДК 004.942

Л. С. Сікора ${ }^{1}$, Н. К. Лиса ${ }^{1}$, Р. Л. Ткачук², Б. І. Федина³, В. І. Кунченко-Харченко4

${ }^{1}$ Начіональний університет "Львівська політехніка", м. Львів, Україна

${ }^{2}$ Львівський державний університет безпеки життєдіяльності, м. Львів, Україна

${ }^{3}$ Українська академія друкарства, м. Львів, Україна

${ }^{4}$ Черкаський державний технологічний університет, м. Черкаси, Україна

\title{
ІНТЕГРАЦІЯ ІГРОВИХ, СИСТЕМНИХ ТА ІНФОРМАЦІЙНО-РЕСУРСНИХ КОНЦЕПЦІЙ ОЦІНКИ ЕНЕРГОАКТИВНОЇ ВЗАЄМОДІЇ ТЕХНОГЕННИХ І ЕКОЛОГІЧНИХ СИСТЕМ (Ч. 2)
}

Сучасний прискорений розвиток техногенних виробничих структур призвів до росту концентрації шкідливих викидів та їх об'єму в екосередовище (грунт, воду, атмосферу), зріс рівень забруднення сіл, міст, цілих регіонів. Ускладнення технологічних процесів, ріст виробничих потужностей теплових електростанцій, транспорту, нафтогазової промисловості, у структуру яких входять енергоактивні об'єкти, ускладнив процеси управління, що призвело до зниження в певних галузях рівня безпеки їх функціонування та підвищило ризики аварій та катастроф. При цьому рівень ризиків аварій і техногенних катастроф залежить від багатьох факторів і компонент надійності систем: надійність і якість проектів техногенних систем, моделей і алгоритмів функціонування; якість конструкцій, агрегатів, комплектуючих, способу їх монтажу; відповідність побудованих структур до проектних вимог, методів їх налагодження та випробування для введення в експлуатацію; якість стратегій, алгоритмів опрацювання даних та прийняття управлінських рішень; якість підготовки (інженерної, знаннєвої, практичної...) виробничого й адміністративного персоналу, а також їхніх позитивних і негативних ознак; підготовка ресурсів для виконання виробничого процесу та їх якості; здатність протистояти ресурсним та інформаційним атакам на техногенну систему; здатність протистояти інформаційним та ментально-психологічним атакам на оперативно-керуючий персонал при прийнятті управлінських рішень. Усі ці аспекти оцінки ризиків мають як стратегічний, так й ігровий характер і визначають динаміку процесів у техногенних системах, а також рівень і характер впливу на екологічне середовище. Для вирішення цієї проблеми виділено, розв'язано та розроблено такі задачі та методи: визначено та оцінено актуальність проблеми мінімізації ризиків техногенних систем на екологічне середовище; проаналізовано літературні джерела, в яких розглядають цю проблему; сформульовано мету дослідження та методи розв'язання задач; проаналізовано причини і фактори виникнення конфліктних ситуацій як технічного, так й інформаційного характеру; проаналізовано і побудовано ігрові моделі стратегій управління; розроблено метод розв'язання конфліктів у техногенних системах; розроблено метод структуризації системи та iï агрегації; розглянуто системну гру та спосіб ії представлення; побудовано загальну схему взаємодії техногенних систем, які формують шкідливі викиди, з екологічним та соціальним середовищем, як основу вироблення координаційних стратегій екозахисту та технології глибинного перероблення відходів; виявлено нові техногенні характеристики та їхній характер і вплив на екологічне середовище.

Ключові слова: система; гра; стратегія; екосистема; інформація; дані; управління; рішення; мета; прийняття рішень.

Вступ. Проблемні задачі управління техногенними системами з енергоактивними об'єктами актуальні як в енергетиці, нафтохімічній галузі, авіації, транспорті та соціальних структурах, оскільки від якості стратегій управління ресурсами і об'єктами залежить рівень забруднення екосередовища регіонів, у яких вони функціонують. Для вирішення проблеми підвищення ефективнос- ті виробничих структур, щодо зниження рівня забруднення, потрібно сформувати відповідний рівень підготовки персоналу, який би володів знаннями різного рівня - від технологічних до системних інформаційних технологій. Вирішення цієї задачі дасть змогу запровадити довгочасний вплив нешкідливих технічних викидів в екосередовище регіону, де розташовані потен-

\section{Інформація про авторів:}

Сікора Любомир Степанович, д-р техн. наук, професор, кафедра автоматизованих систем управління.

Email: Issikora@gmail.com; https://orcid.org/0000-0002-7446-1980

Лиса Наталія Корнеліївна, канд. техн. наук, асистент, кафедра інформаційних систем та технологій. Email: Іуsa.nataly@gmail.com

Ткачук Ростислав Львович, канд. техн. наук, доцент, кафедра цивільного захисту та комп'ютерного моделювання екогеофізичних процесів. Email: rlvtk@ukr.net

Федина Богдана Іванівна, канд. техн. наук, ст. викладач, кафедра автоматизації та комп'ютерних технологій. Email: fedynabogdana@gmail.com

Кунченко-Харченко Валентина Іванівна, д-р техн. наук, професор, завідувач кафедри інформатики, інформаційної безпеки та документознавства. Email: itib@chdtu.edu.ua

Цитування за ДСтУ: Сікора Л. С., Лиса Н. К., Ткачук Р. Л., Федина Б. І., Кунченко-Харченко В. І. Інтеграція ігрових, системних та інформаційно-ресурсних концепцій оцінки енергоактивної взаємодії техногенних і екологічних систем (Ч. 2). Науковий вісник НЛТУ України. 2019, т. 29, № 1. С. 126-135.

Citation APA: Sikora, L. S., Lysa, N. K., Tkachuk, R. L., Fedyna, B. I., \& Kunchenko-Kharchenko, V. I. (2019). Integration of Gaming, System and Information and Resource Concepts of Assessment of Energy Active Interaction of Technological and Ecological Systems (Part 2). Scientific Bulletin of UNFU, 29(1), 126-135. https://doi.org/10.15421/40290127 
ційно небезпечні об'єкти. Для систем 3 ієрархічною структурою організації управління характерною рисою когнітивної системи оперативного персоналу для прийняття управлінських рішень $є$ наявні розриви у знаннях про структуру об'єктів, процеси автоматичного й оперативного управління, системи відбору й опрацювання даних, необхідних для прийняття як локальних, так і системних рішень на стратегічному рівні ієрархії, які мінімізують ризики аварій завдяки чіткому розумінню виниклих кризових ситуацій.

Актуальність дослідження. Причинними факторами виникнення аварійних ситуацій $є$ помилки у проектуванні, обмеженість знань про структуру технологічних систем та енергосистем, розриви в розумінні інформації про динаміку руйнівних процесів, які можуть виникати під час функціонування енергоактивних об'єктів. Ігрова концепція взаємодії (активні фактори $\leftrightarrow$ техногенні системи) є основою виявлення системної, інформаційної та енергетичної структури процесів руйнування техногенних об'єктів за рахунок накладання непередбачуваних факторів, які через обмеженість знань операторів неможливо врахувати та, відповідно, спрогнозувати.

На підставі ігрових і системних моделей, як основних засад аналізу взаємодії техногенних, екологічних та соціальних систем, потрібно будувати загальні схеми ієрархічної організації регіонального соціуму. Вирішення цієї задачі дасть змогу проаналізувати наявні ресурси для виробництва та життєдіяльності людини і суспільства, оцінити ризики і ймовірність виникнення конфліктів під час розподілення ресурсів. Такий підхід до розв'язання безпеки життєдіяльності дає підставу для глибокого аналізу взаємозв'язків комплексу виробництв 3 ресурсами та екосередовищем і дає змогу забезпечити глибинну переробку небезпечних відходів.

Аналіз літературних джерел. Відповідно до цих задач проведемо аналіз літературні джерела за останній період, які відображають стан проблеми екологічної і техногенної безпеки.

У роботі (Didenko, 1984) розглянуто проблеми створення АСУ-ТП нового покоління на основі мікропроцесорних структур та інформаційних технологій і системного аналізу. У довіднику (Boborykin, 1985) систематизовано відомості про агрегатні комплекси автоматизованих систем управління, структурна організація, методологія системного проектування, без розкриття психології управління.

У праці (Volik, 1985) розглянуто проблему автоматизації управління великими технологічними комплексами, проаналізовано якості управлінських систем, розроблено методи і моделі розрахунків показників ефективності процесу управління, наведено математичний апарат, але не враховано когнітивну компоненту прийняття управлінських рішень.

У монографії (Smoliakov, 1986) розглянуто теорію прийняття рішень і процедури побудови рівноважних стратегій у разі незбігу стратегічних інтересів корпоративних гравців, розглянуто методи подолання конфліктних ситуацій на підставі системного аналізу.

У праці (Perkhach \& Podolchak, 2014) розглянуто причини виникнення та способи подолання корпоративних конфліктів, методи захисту та діяльність в умовах загроз на підставі класичного підходу до аналізу ситуацій.
У роботі (Kunchenko-Kharchenko, 2015) розглянуто концепцію захисту інформації в системах документообігу в ієрархічних системах управління.

У монографії (Chikrii, 1992) розглянуто методи розв'язання ігрових задач управління в конфліктних ситуаціях у системах зі складною структурою, конфліктну керованість об'єктами в швидкоплинних динамічних ситуаціях.

У монографії (Krapivin, 1972) розглянуто методи синтезу складних системних моделей на підставі теоретико-ігрової концепції прийняття рішень, а також ігри в технічних системах 3 неповною інформацією, термінальні рішення на підставі системного аналізу.

У роботі (Druzhinin \& Kontorov, 1982) викладено принципи системного дослідження виникнення конфліктів між складовими системами, при розподілі цільових ресурсів у процесах прийняття рішень у невизначених ситуаціях, методи оцінки ефективності прийняття рішень, процедури побудови вирішних правил, виявлення сигналів на фоні завад, моделі конфліктів, залежно від цілей і ситуацій.

У монографії (Pavlov, 1982) розглянуто способи розв'язання конфліктних задач, які виникають у технічних системах, ігрові моделі прийняття рішень у взаємодії "Людина ↔ АСУ", ситуаційне управління об'єктами.

У праці (Pospelov, 1986) вперше розроблена парадигма ситуаційного управління, як метод управління складними системами технічного і організаційного класу 3 використанням теорії штучного інтелекту, теорії знань, логіки прийняття рішень.

У монографіï (Roberts \& Geiman, 1986) викладено методи дискретної математики, які використовуються для моделювання складних систем різної природи. Проаналізовано задачі прийняття рішень, логіки групового вибору стратегічної поведінки систем, способи і методи опису ситуацій.

У роботі (Sviridov, 1978) розглянуто проблему відбору даних, як основи достатності інформації про стан об'єкта, що необхідно для прийняття рішень на управління.

У роботі (Druzhinin \& Sergeeva, 1990) розглянуто та викладено основні засади та методи оцінки якості інформації для прийняття рішень у виробничих системах. Розроблено методи оцінки достовірності даних про стан об'єктів та методи опису динамічних режимів. Обгрунтовано метод синтезу структур оброблення даних.

У роботі (Gladun, 1987) розглянуто теоретичні i прикладні питання створення систем генерації цілеорієнтованих планів розв'язання задач управління. Обгрунтовано методи представлення знань, стратегій прийняття рішень в умовах невизначеності на підставі логічних правил і процедур.

Методи побудови логічних висновків у процесах формування рішень особою розглянуто в (Pospelov, 1989), описано дедуктивні, індуктивні та правдоподібні моделі мислення людини, які є підставою формування управлінських дій.

У роботі (Akoff \& Emeri, 1974) викладено основи теорії вимірювань некількісних ознак, шкал, яка є інструментом оброблення даних та інформації, методи інтервального аналізу, як інтелектуальної основи аналізу цілеспрямованих дій та побудови цілеспрямованих систем.

У фундаментальному посібнику (Barsegian, 2009) викладено основи інтелектуального оброблення потоків 
даних, теорію сховищ даних, аналіз образів та текстової інформації, агентні системи, нейронно-чіткі моделі і витяг знань.

У роботі (Zaitcev, 1990) визначено способи підвищення ефективності та якості роботи операторів у системах автоматизованого управління технічними комплексами, розглянуто, на підставі системного аналізу, оперативну діяльність людини, діалоги у процесі рішень на основі класичної інженерної психології.

У роботі (OKonor \& Makdermat, 2018) проаналізовано способи мислення у прийнятті рішень за різних ситуацій, сформульовано концепцію системного мислення особи.

У збірнику праць (Mekhanizmy, 1972) розглянуто математичні аспекти побудови моделі цілеспрямованої поведінки особи під час формування рішень та психології дій.

У монографії (Blinov \& Petrov, 1991) досліджено основні проблеми логіки дії, динамічні та статичні аспекти означення дії, семантика, теоретико-ігрові моделі процесів рішень, на яких формуються засади управління.

У роботі (Kheis, 1981) розглянуто концепцію причинності, виявлення причинно-наслідкових зв'язків при аналізі ситуацій у складних системах, динаміку поведінки особи у процесі декомпозиції складних ситуацій.

У монографіï (Kheili \& Kumamoto, 1984) викладено методи аналізу надійності і безпеки технічних систем, аналітичний аналіз і методи ймовірного моделювання та способи оцінювання ризиків виникнення аварійних ситуацій.

У монографії (Palamarchuk, 1992) розглянуто теоретичні системні і логіко-математичні основи суспільнотериторіальних комплексно утворених та інформаційно узгоджених структур, проблеми взаємодії суспільства 3 природою та моделі інтеграції наук, розроблено теорію формування структур.

Монографії (Marshal, 1989; Draizdel, 1990) присвячені методам аналізу ризиків та безпеки промислових підприємств, розглянуто основні причини аварій, їх наслідки, аналіз ризиків.

У монографіï (Sikora, 1998) сформовано основні положення інформаційно-ресурсної концепції аналізу i синтезу структури систем управління складними об'єктами. Розроблено методики формування стратегій управління в цільовому просторі системи в умовах дії збурень на підставі ігрової та ресурсно-інформаційної концепцій.

У монографіï (Sikora, 1999) на підставі інформаційно-ресурсної концепції, розробив автор, обгрунтовано метод ідентифікації структури і динаміки поведінки складних систем в умовах дії збурень, розглянуто ігрові моделі взаємодії.

У праці (Sikora, 2001), базуючись на системному аналізі та інформаційно-ресурсній концепції синтезу моделей динаміки і структури об'єктів, викладено методи синтезу робастних структур управління технологічними системами.

У роботі (Sikora, Medykovskyi \& Hrytsyk, 2002) обгрунтовано концепції енергоактивності об'єктів управління та розроблено методи оброблення потоків даних на підставі перспективних інформаційних технологій.

У праці (Medykovskyi \& Sikora, 2002) на підставі концепції енергоактивності розроблено метод синтезу моделей систем, структур управління, методи опрацювання даних на підставі інтервальних статистик.

У праці (Tkachuk \& Sikora, 2010) на підставі системного аналізу і когнітивної технології обгрунтовано методи логіки прийняття рішень в екстремальних ситуаціях, нечіткості даних та процедури побудови стратегій.

У фундаментальній праці (Drahan, Sikora \& Yavorskyi, 2014) на підставі системного аналізу і енергетичної теорії (Я.П. Драган), викладено основи теорії стохастичних сигналів.

У працях (Durniak, et al., 2013a, 2013b, 2017) на підставі системного аналізу та логіко-когнітивних моделей розглянуто методи формування й прийняття рішень в цілеспрямованих системах управління 3 ієрархічною структурою в умовах ризику аварій і конфліктів. Розглянуто лазерні технології відбору і опрацювання даних від енергоактивних об'єктів для забезпечення прийняття рішень у системах управління й екомоніторингу.

У колективній роботі (Bychenok, et al., 2000) обгрунтовано концепцію створення регіонального центру для прийняття рішень зі забезпечення захисту населення та об'єктів життєзабезпечення від АЕС, гідроспоруд, землетрусів.

У статті (Vasylenko, 2017) розроблено базову концепцію міжнародної екологічної безпеки, яка грунтується на діалозі державних структур, уряду, вчених, бізнесу і громадським суспільством.

У статті (Shapar \& Mikheiev, 2018) розглянуто процеси дестабілізації екологічних систем під впливом техногенних структур-забруднювачів, розглянуто стратегії сталого розвитку та процес руйнування механічних систем та їхнє інформаційне трактування.

У фундаментальній праці (Drahan, 1997) розглянуто енергетичну теорію стохастичних сигналів, як базис аналізу факторів.

У роботах (Timoshenko, 1967; Tivilov, 1988; Karzov, Margolin \& Shvetcova, 1993) розглянуто методи аналізу динаміки поведінки складних систем, контроль стану, виявлення факторів активного руйнування структури техногенних об'єктів, контролю стану.

У праці (Sikora, 1988) розглянуто методи побудови лазерних систем для контролю вібраційних процесів енергоактивних об'єктів.

У праці (Mesarovich, Mako \& Takakhara, 1973) розглянуто проблеми управління великими ієрархічними системами, що пов'язані з введенням поняття стану системи, іï керованістю та реалізацією, а також можливостями ії структурної декомпозиції.

Мета дослідження - провести системний аналіз процесів виникнення конфліктних ситуацій в екосистемах, соціальних та техногенних системах і дослідити вплив активних факторів та шкідливих викидів на їх функціонування на підставі ігрової концепції узгодження стратегій цільового управління енергоактивними об'єктами з вимогами екологічних державних нормативів та соціальних структур.

Задачі дослідження. На підставі системно-ігрової концепції прийняття цільових рішень:

- проаналізувати системну гру під час конфлікту ресурсів;

- обгрунтувати модель динаміки потоків ресурсів;

- обгрунтувати процедуру адаптації стратегій управління;

- розробити метод розв'язання конфліктних ситуацій.

Методи дослідження - провести системний аналіз, застосувати інформаційні технології опрацювання да- 
них, використати методи синтезу стратегій антикризового управління, теорію ігор, когнітивні процеси прийняття рішень та інтерпретації ситуацій.

1. Системна гра цілеоріснтованих технологічних структур у граничних режимах розподілу ресурсів. Розглянемо основні схеми взаємодії учасників парної інформаційної гри у структурі технологічної системи. Відповідно задано такі структури учасників гри (Sikora, 1998, 1999, 2001; Sikora, Medykovskyi \& Hrytsyk, 2002; Medykovskyi \& Sikora, 2002; Tkachuk \& Sikora, 2010):

- $\{I V F \otimes C U S\}_{P}$ - фактори збурення параметрів системи $C U S$ джерелом завад $I V F$, яке має канали впливу на технологічний процес;

- $\left\{C U S_{1} \otimes C U S_{2}\right\}_{S t r}$ - фактор збурення структури системи $C U S_{2}$, як противником реалізації цілі функціонування (розрив функціональних зв'язків);

- $\left\{C U S_{1} \otimes C U S_{2}\right\}_{\text {Strat }}$ - фактори збурення стратегій системи $C U S_{2}$ за рахунок дезінформації (при оцінці параметрів траєкторії стану);
- $\left\{C U S_{1} \otimes I R\right\} \otimes\left\{C U S_{2}, I R\right\}$ - боротьба за ресурси між структурами $C U S_{1}$ і $C U S_{2}$ (матеріальні, енергетичні, інформаційні, фінансові);

- $\left\{T Б_{i} \otimes T Б_{j} \mid C u s\left[\right.\right.$ Strat $\left.\left.U \mid C_{T \Pi}\right]\right\}$ - pecyрсні конфлікти та гонки між технологічними блоками.

Стан системи визначається через баланс ресурсів у дослідній структурі, за наявним ефективних стратегій гри, яка визначає їх розподіл залежно від навантаження енергоактивних агрегатів (Sikora, 1998, 1999, 2001):

$$
\begin{gathered}
{\left[\sum_{i=1}^{m} \Phi_{b x_{i}}^{R}(U, \tau, \xi)-\sum_{j=1}^{m} \mu_{j} \Phi_{\text {вux }}^{P R}(t, \eta)\right]=\Delta \Phi(U, \xi, \eta, t),} \\
\exists \operatorname{Strat}_{\Phi R}\left(C_{i}\right): \Delta \Phi(t) \subset I_{\Delta o p t} \triangleq\left[z_{C}-\varepsilon, z_{C}+\varepsilon\right] \mu_{F Z}, \\
\forall|\xi(t)| \leq \alpha_{0}, \quad \forall|\eta(t)| \leq \beta_{0},
\end{gathered}
$$

де $z_{C} \in V_{\varepsilon}(C \mid R \times)$ - параметр цільового стану технологічної системи.

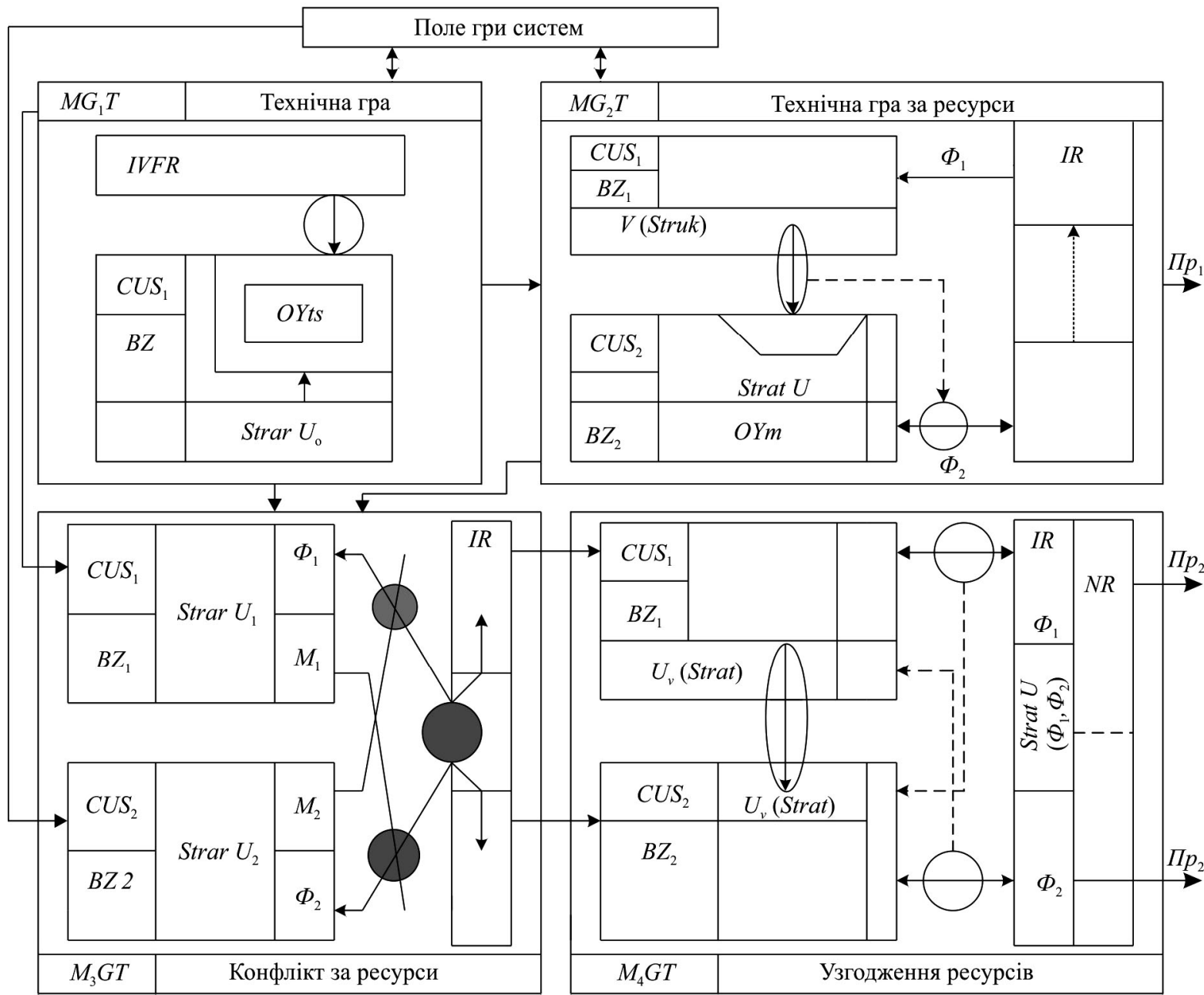

Рис. 1. Структурні моделі сценаріїв взаємодії конкуруючих систем при парній грі: $Z(t) \in I_{Z} \subset R-$ реалізація траєкторії стану,

$\operatorname{dim} I_{Z}=[\max Z-\min Z]-$ допустимі границі інтервалу параметра стану, $G R A F(Z(t))=\underset{Z, t}{E}\left\{(Z(t), t) \in I_{Z} \times T_{n}\right\}-$ графік просторової структури траєкторії в просторі стану $\left[I_{Z} \times T_{n}\right], Z_{0}$ - початковий стан системи, $\left[I_{Z} \times I_{Z d / d t}\right]-$ фазовий простір, CUS $S_{\mathrm{i}}-$ цілеспрямована система. Відповідно сценарії розвитку подій у грі будуть $M_{1} G T$ - технологічна гра в структурі $C U S_{1}, M_{2} G T-$ модель взаємодії за розподіл ресурсів, $M_{3} G T$ - модель конфлікту за перерозподіл матеріальних і енергетичних ресурсів, $M G_{n}-$ стратегія узгодження інтересів

Загальний баланс матеріальних ресурсів за термінальної стратегії прийняття рішень на управління згідно з режимом навантаження описується через поведінку моделі траєкторії випадкового процесу, яка формується на осно- ві взаємодії в технологічній структурі локальних компонент потоків поступаючих і використаних ресурсів та відображає динамічний стан системи через траєкторію динаміки балансу у вигляді інформаційного образу ситуації 
в області стійкого функціонування. Структура цільового простору визначається процедурою (стратегією) розв'язання проблемної цільової задачі, моделями простору станів і фазового простору об'єкта управління та його енергетичними характеристиками взаємно спряженими через ізоморфні оператори динаміки об'єкта. На основі вивчення ситуаційної поведінки рівня траєкторії стану ОУ, при виконанні умов балансу ресурсів, формуються процедури класифікації можливих станів об'єкта управління і стратегій руху до цілі (Sikora, 1998, 1999, 2001; Sikora, Medykovskyi \& Hrytsyk, 2002; Medykovskyi \& Sikora, 2002; Tkachuk \& Sikora, 2010; Drahan, Sikora \& Yavorskyi, 2014; Durniak, et al., 2013a, 2013b, 2017; Mesarovich, Mako \& Takakhara, 1973).

Для імпульсних потоків модель траєкторії стану визначається на підставі моделювання динаміки згідно 3 рівнянням (нелінійного) балансу ресурсів, відносно області стійкої рівноваги, в умовах дії збурень і обмежень на ресурси:

$$
\begin{gathered}
\operatorname{GRAF}\left[Z\left(t \mid T_{n}\right)\right]= \\
=Z_{0}+\int_{t}^{t+T_{n}} A_{Z \Phi}(t, \theta)\left[\sum_{i=1}^{m} \Phi_{b x}\left(t, U_{i}\right)-\sum_{j=1}^{m} \Phi_{\text {вux }}(t, \xi) d t\right],
\end{gathered}
$$

відповідно до моделі гри в двох конкуруючих системах (рис. 1).

2. Динаміка потоків ресурсів у грі. Для кожного учасника гри, як інтелектуальної системи, що приймає рішення, спрямовані для досягнення цілі, характерною ознакою $є$ спосіб формування стратегій управління 3 урахуванням можливої поведінки конкурента, виходячи 3 рівнянь динаміки, які описують поведінку гравців у цільовому просторі як кожного гравця, так і спільному. Динаміка взаємодії гравців визначається спільним розв'язком системи рівнянь на інтервалі часу $\left(T_{n}\right)$ відповідно до розподілу наявних ресурсів і цілей (Sikora, 2001; Sikora, Medykovskyi \& Hrytsyk, 2002; Medykovskyi \& Sikora, 2002; Tkachuk \& Sikora, 2010):

$$
\left\{\begin{array}{l}
\frac{d Z_{1}(t)}{d t}=F_{1}\left(x_{1}, U_{1}, t\right)+F_{12}\left(U_{2}, \xi_{2}, t\right), \exists U_{!} \in \operatorname{Strat}\left(\frac{U}{C_{1}}\right), \forall t \in T_{n} ; \\
\exists \operatorname{PRPSyt}\left(\operatorname{Strat}\left(\frac{U}{C_{1}}\right) \stackrel{I_{S}}{\longrightarrow} \operatorname{Strat}\left(\frac{t}{C_{2}}\right)\right) \\
\frac{d Z_{2}(t)}{d t}=F_{2}\left(x_{2}, U_{2}, t\right)+F_{21}\left(U_{1}, \xi 1_{2}, t\right), \exists U_{2} \in \operatorname{Strat}\left(\frac{U}{C_{2}}\right), \forall t \in T_{n},
\end{array}\right.
$$

Стратегії управління базуються на концептуальних моделях класифікації ситуацій, тобто оцінці належності траєкторії стану до означеного, за певними критеріями, класу цільового простору і вибору команди управління, яка переводить систему у відповідній цільовій задачі клас. Задано таку структуру розбиття класів, як $n$-мірних множин: $\left\{K_{i}\right\}_{i=1}^{m} \times T_{n} \hat{=} K L_{I}-$ інваріантна системна класифікація розбиття простору цілей на неперервному інтервалі часу функціонування ігрової структури; $\left\{K_{i}\right\}_{j=1}^{m} \times\left\{T_{K}\right\}_{K=1}^{m} \hat{=} K L_{l I}-$ локально-інваріантна класифікація розбиття цільового простору і станів, відносно термінальних циклів управління.

На рис. 2 наведено модель ігрової системи в конфліктній боротьбі за розподіл ресурсів. Введення такого розбиття класів дає змогу сформувати принципи синтезу локальних і глобальних стратегій поведінки на основі методів їх ресурсного та ситуаційного управління Д. Поспелова (Pospelov, 1986).
Методологія i системологія аналізу динаміки траєкторії стану технологічної системи, виходячи з рівнянь балансу ресурсів, базується на методах параметричної і непараметричної статистик, теорії прийняття рішень в умовах невизначеності, теорії перевірки статистичних гіпотез, що дає змогу сформувати індикатори положення системи відносно базових координат цільового простору на основі оцінок статистик про належність образів динамічних ситуацій у поточному часі до альтернативних класів еталонних моделей розбиття простору станів. Кожному класу відповідають локальні стратегії прийняття цільових рішень (які $є$ елементами глобальної політики), що дає змогу під дією послідовності управлінських команд перевести систему у цільову область, тобто описують процедуру розв'язання проблемної задачі розподілу ресурсів в цільовому просторі системи та уникнення конфліктної ситуації.

3. Адаптація стратегій. У випадку ситуації, коли цільова задача не розв'язана, формуються процедури (за наявності ресурсів) адаптації стратегій досягнення цілі в умовах дій збурень і завад, які базуються на додатковому вивченні проблемної задачі. Це потребує створення нової моделі проблеми і цільової ситуації у технологічній структурі, оцінки наявних ресурсів, що призводить до зміни траєкторії руху і термінального часу (Sviridov, 1978; Druzhinin \& Sergeeva, 1990; Gladun, 1987; Pospelov, 1989; Akoff \& Emeri, 1974; Barsegian, 2009; Zaitcev, 1990; OKonor \& Makdermat, 2018; Mekhanizmy, 1972; Blinov \& Petrov, 1991).

Синтез стратегії досягнення цілі, в системі управління зі зворотнім зв'язком, базується на уточненні моделі цілі і способів ії реалізації за обмежених ресурсів, як процедури розв'язку цільової задачі. Синтез поведінки системи, при заданій структурі в умовах дії збурень i великих за рівнем завад, грунтується на використанні типових моделей стратегій досягнення цілей, що відображаються через смуги напрямку можливих траєкторій руху в цільовій області. Оцінка порогових збурень, які приводять до технологічного збою за рахунок спотворення інформації про стан системи в режимі оцінки ситуації і прийняття рішень, є основою вибору класів алгоритмів оброблення сигналів 3 робастними властивостями. Синтез стратегій корекції режимів і параметрів системи при еволюції об'єкта управління і системи спостереження, контролю і управління, базується на методах і процедурах, алгоритмах розв'язку цільової задачі, які верифіковані по класах еталонних розв'язків проблем. Ефективна оцінка сильних завад і корекція оптимальних алгоритмів оброблення сигналів і забезпечення їх робастності, їх адекватна фільтрація від завад 3 точки зору отримання коректної інформації для формування образу ситуації в цільовому просторі є основою прийняття рішень в умовах невизначеності динамічної ситуації відносно цілі. Корекція алгоритмів оброблення даних для формування образів динамічної ситуації базується на процедурах оцінки поведінки функціоналів якості в зонах дії збурень. Корекція моделей об'єкта управління і стратегій досягнення цілей проводиться (в умовах кризи), виходячи з наявності процедур розв'язку проблемних задач, для чого необхідно провести (Sikora, 2001; Sikora, Medykovskyi \& Hrytsyk, 2002; Medykovskyi \& Sikora, 2002; Tkachuk \& Sikora, 2010): 


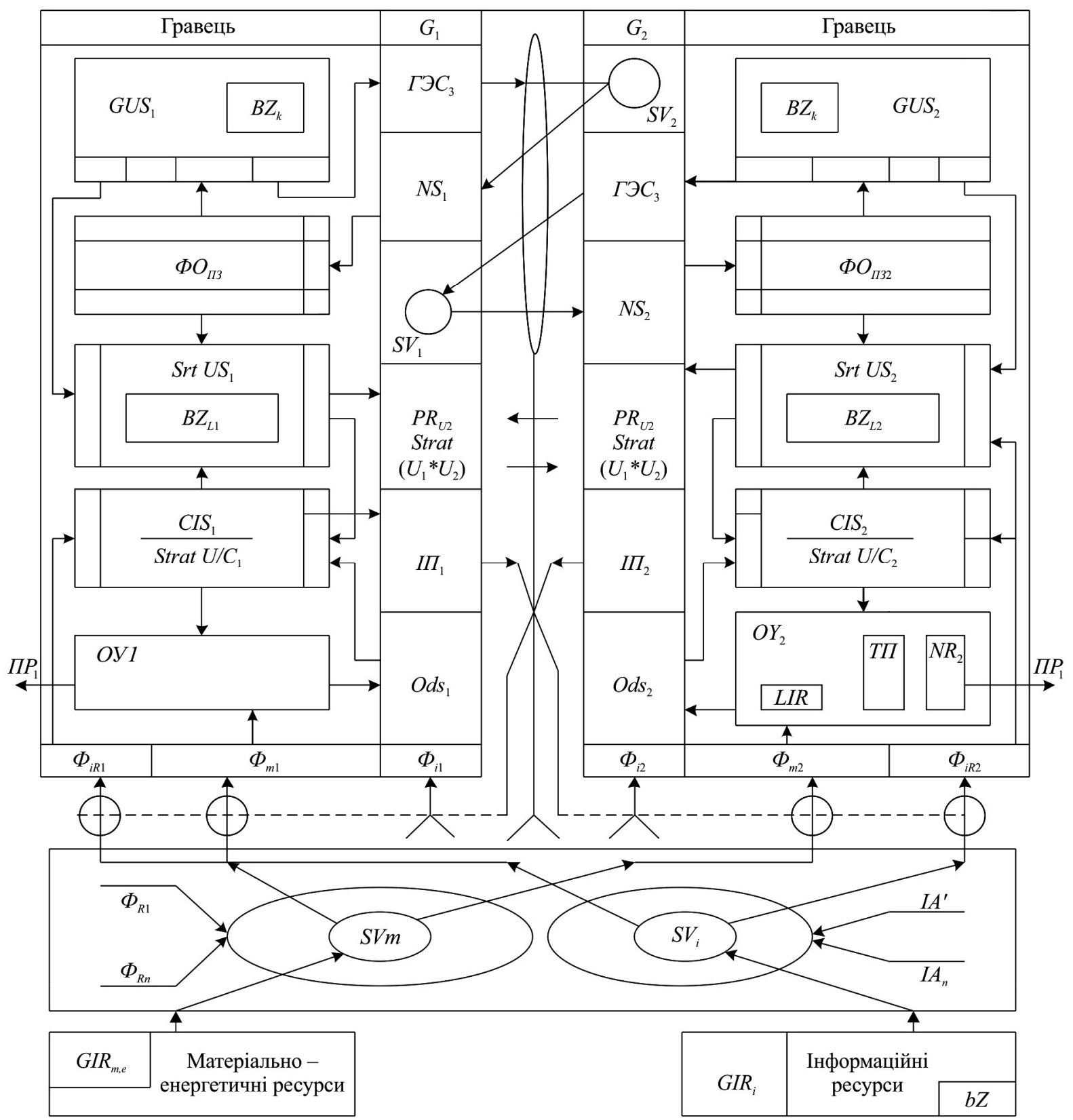

Рис. 2. Модель ігрової системи, яка використовує спільне джерело ресурсів на підставі узгодження стратегій безконфліктної гри: $N S_{i}$ - спостережні інформаційні системи; $O d s_{i}-$ образи динамічної ситуації в об'єкті гри; $\Phi R_{i}-$ фактори впливу на ресурси; $I A_{i}-$ iнформаційні атаки; $\left\{G I R_{m i}\right\}$ - глобальні системи постачання ресурсів; $G_{1}, G_{2}-$ гравці; $S V$ - зони взаємодії; $\Pi \Gamma_{1,2}-$ поле гри; $Г 3 C_{3}-$ генерація зондуючих сигналів для відбору даних; $P R_{i}-$ потоки ресурсів; $B Z L_{\mathrm{i}}-$ бази логічних правил; $\Phi_{i p}-$ фактори впливу на ресурсні та інформаційні потоки; $S V_{m}, S V_{i}$ - області розподілу потоків ресурсів та інформації

• перевірку умов досягнення цілей та оцінку засобів і об'ємів ресурсів;

- оцінки степенів наявності і мобільності ресурсів для реалізації цілей у критичних умовах;

• корекції стратегії входження в цільову область і степені доступності наявних ресурсів у момент конфлікту.

Оптимізація режиму виходу з кризової ситуації системи проводиться з урахуванням знань про структуру, динаміку і цільову задачу системи і базується на формуванні функціоналу якості, компонентами якого будуть індикаторні функції економії ресурсів, термінального часу досягнення цілі, точності підтримання функціонального стану. Оптимізація алгоритмів оброблення сигналів і стратегій управління для кожного учасника гри в технологічній структурі проводиться, виходячи 3 структури цільової задачі на вивченні статистичних характеристик траєкторії сигналів і завад, а також на основі перевірки відповідності моделей сигналів алго- ритмам обробки, виконуються умови забезпечення їх робастності і інформаційної адекватності, при виконанні умови узгодження стратегій спільного розподілу ресурсів (Chikrii, 1992; Krapivin, 1972; Druzhinin \& Kontorov, 1982; Pavlov, 1982; Pospelov, 1986) (рис. 3).

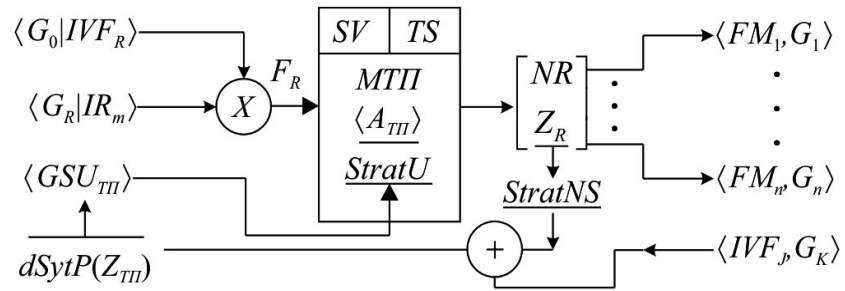

Рис. 3. Учасники технологічної гри: $T S$ - технологічна система, як зона взаємодії; $G_{0}$ - гравець, який відображає фактори збурення потоку ресурсів; $G_{K}-$ збурення інформаційних каналів; $G_{R}$ - модель джерела ресурсів, які забезпечують технологічний процес; $\left\{G_{1}, \ldots, G_{n} / F M\right\}$ - формуючі машини (керовані сторон- 
нім оператором); $\left\{G S U_{T \Pi}\right.$ / Strat $U$, Strat $\left.N S\right\}$ - система керування технологічним процесом, як узгоджувач режиму гарантованого балансу розподілу ресурсів 3 вибраним класом стратегій спостереження і управління, узгоджених з цільовою задачею

4. Метод розв'язання конфліктних ситуацій. Проблема розв'язку конфліктних ситуацій у технологічних структурах, при взаємодії активних, пасивних учасників гри, вимагає для свого розв'язання створення комплексу концептуальних моделей, як впорядкованої інтелектуальної бази знань, що містить в собі блоки взаємозв'язаних моделей структури і динаміки систем стратегій управління і оптимізації, моделей процедур синтезу САУ-ТП і на їх основі проведення синтезу концептуальної моделі технологічної структури, іiї параметризація відносно цільового і простору станів, визначення граничних і аварійних режимів. Зазначені параметризовані концептуальні моделі перевіряються на стійкість за Ляпуновим, при дії збурень з еталонними ймовірнісними характеристиками (Chikrii, 1992; Krapivin, 1972; Druzhinin \& Kontorov, 1982; Pavlov, 1982; Pospelov, 1986; Sikora, 1998, 1999, 2001; Sikora, Medykovskyi \& Hrytsyk, 2002; Medykovskyi \& Sikora, 2002; Tkachuk \& Sikora, 2010; Drahan, Sikora \& Yavorskyi, 2014; Durniak, et al., 2013a, 2013b, 2017).

Сукупність вимог до точності і стабільності САУТП і оцінки параметрів реакції на збурення визначають ступінь грубості і $є$ інформаційною основою синтезу робастних алгоритмів виявлення й опрацювання сигналів, які циркулюють по інформаційних каналах АСУТП. Викладена концепція $є$ основою синтезу безконфліктних стратегій розподілу ресурсів та їх інформаційного забезпечення (Sikora, 1998, 1999, 2001; Sikora, Medykovskyi \& Hrytsyk, 2002; Medykovskyi \& Sikora, 2002; Tkachuk \& Sikora, 2010; Drahan, Sikora \& Yavorskyi, 2014; Durniak, et al., 2013a, 2013b, 2017).

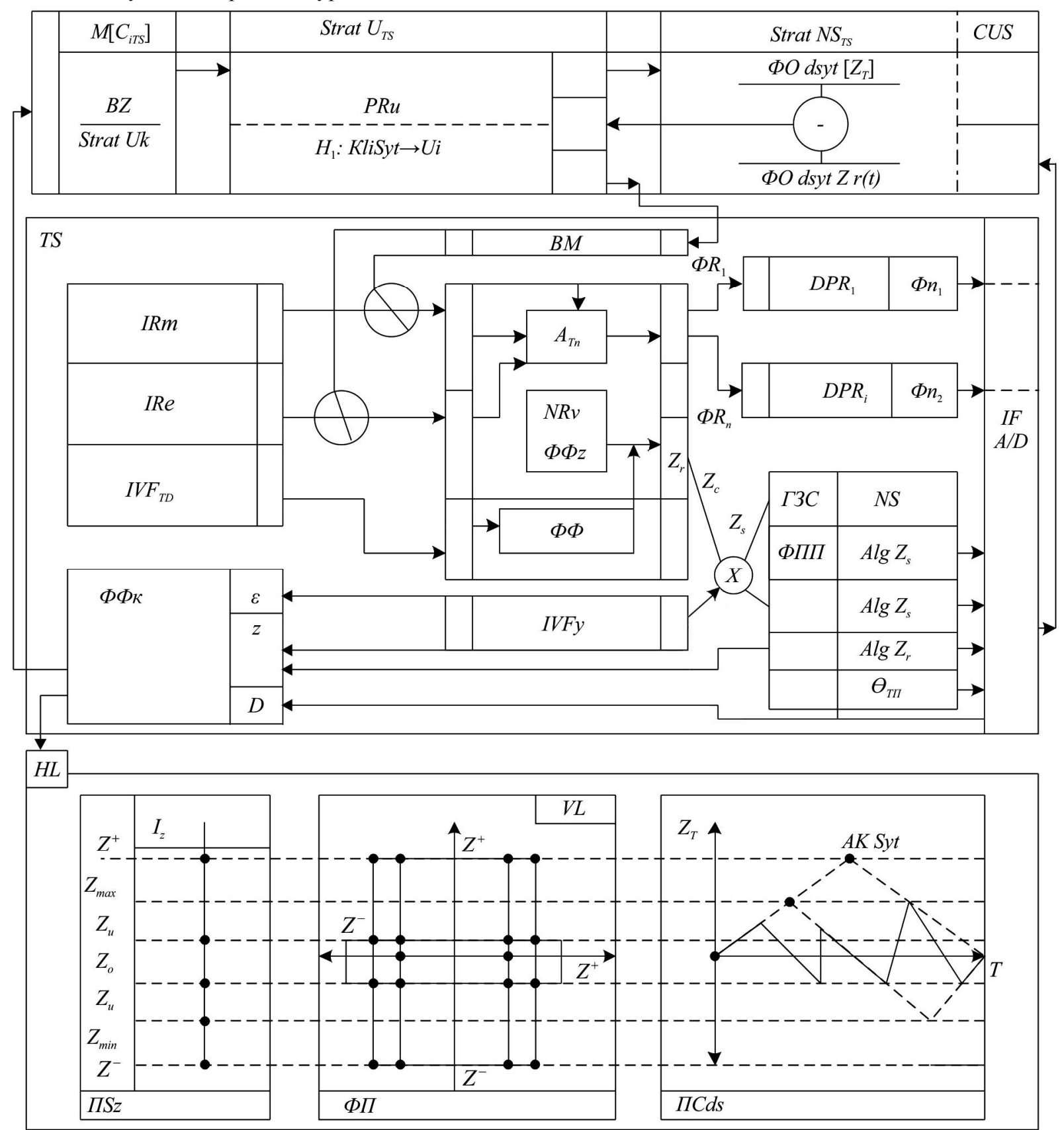

Рис. 4. Модель вибору режиму гри $<C U S \vec{\leftarrow} T S>$ 
Побудували на основі концептуальної моделі $K M\left[S U_{T \Pi}\right]_{B Z}$ - системи управління $i$-го класу, яка визначена алгоритмом розв'язку проблемної цільової задачі, параметричні моделі (Sikora, 1998, 1999, 2001; Sikora, Medykovskyi \& Hrytsyk, 2002; Medykovskyi \& Sikora, 2002; Tkachuk \& Sikora, 2010; Drahan, Sikora \& Yavorskyi, 2014; Durniak, et al., 2013a, 2013b, 2017). Для цього потрібно побудувати такі компоненти системи:

1. $\mathrm{S}_{\mathrm{Z}}$ - простору станів з інтервалами:

- $I_{R}=\left\{Z_{U}^{-}, Z_{0}, Z_{U}^{+}\right\}$- нормального режиму;

- $I_{m}=\left\{Z_{\max }^{+}, Z_{\max }^{-}\right\}$- допустимих викидів;

- $I_{A}=\left\{Z_{A}^{+}, Z_{A}^{-}\right\}-$аварійних областей.

2. $Ф П\left(Z_{T \Pi}, \dot{Z}_{T \Pi}\right)$ - фазовий простір з набором ляпуновських областей стійкості $\left\{\left|Z_{T}^{+}, Z_{T}^{-}\right|,\left|\dot{Z}_{T}^{+}, \dot{Z}_{T}^{-}\right|\right\}$динамічного режиму, що визначають область функціонування при дії збурень і зміні інтенсивності потоків $\left\{\Phi_{R_{1}}, \Phi_{R_{n}}\right\}$ на формуючі машини;

3. $\Pi C d s\left(\hat{Z}_{T} / T_{n}\right)$ - цільовий простір на $\left\{I_{Z} \times R_{T}\right\} C_{U_{i}}$ термінальному базисі $i$-го циклу управління $\left\{C U_{i}\right\}$ на основі моделі балансу ресурсів відносно стану рівноваги $\left\{Z_{0}\right\}_{S R}^{D S}$ :

$$
\begin{gathered}
\hat{Z}_{T \Pi}\left(\frac{t}{T_{n}}\right)=Z_{0}+\int_{t_{0}}^{t} A_{T \Pi}(Z, \dot{Z}, t, \tau, \theta) \times \\
\times\left[\Phi_{\text {gx }}(U(\tau), t, \xi)-\sum_{i=1}^{m} \Phi_{\text {gux }}(t, \theta, \eta)\right] d t+Z_{\xi}(t) .
\end{gathered}
$$

4. Модель вибору простору гри та динамічного опису ситуації при виконанні управляючих дій.

На рис. 4 наведено схему вибору режиму гри згідно 3 цілями і стратегіями поведінки щодо режиму та потужності ресурсів. Відповідно до цільового завдання можемо змоделювати поведінку траєкторії стану TS, що відображає зміну рівня режиму і стану при дії збурень на потоки ресурсів та інформаційні канали.

Відповідно, стратегії ігрової поведінки в регіоні розташування промислових техногенних систем залежать як від якості утилізації відходів кожної структури зокрема, так і рівня екоконтролю та директивних та адміністративних параметрів. При неконструктивній конфліктній поведінці ризики посилюються, що може призвести до техногенної катастрофи з викидами шкідливих речовин за відсутності структури для їхньої глибокої переробки і утилізації (рис. 5).

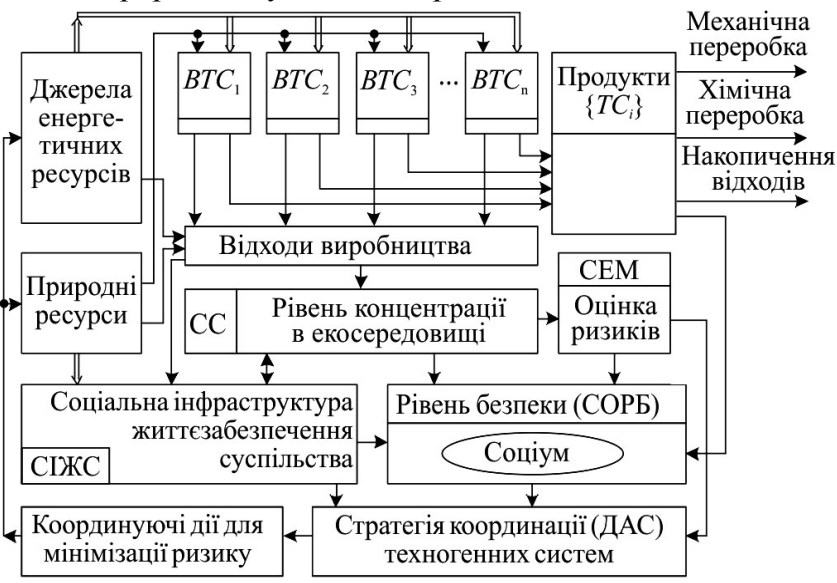

Рис. 5. Схема формування ризиків викидів шкідливих продуктів та їхнього впливу на екосистему
Відповідно, схема формування ризиків впливу шкідливих продуктів на екосистему відображає ієрархію гри, в яку входять такі компоненти (Durniak, et al., 2013b):

- $\left\{B T C_{i}\right\}$ - виробничі технологічні системи;

- ДПР - джерела природних ресурсів (енергоносії, повітря, вода та ін.)

- СІ та ЕС - соціальна інфраструктура та екологічне середовище;

- СС - система сенсорів у структурі системи екомоніторингу (CEM);

- $\mathrm{COPБ}_{\mathrm{TE}}$ - система оцінки рівня технологічної й екологічної безпеки;

- ДАС - державна адміністративна структура, яка виробляе координаційні стратегії для промислових комплексів $\left(B T C_{i} / i \doteq\right)$ виробничих техногенних систем;

- СІЖС - системна інфраструктура життєзабезпечення суспільства - (населення).

Для пошуку необхідної стратегії управління TS необхідно "при дії збурень" провести імітаційну гру в $(\Pi q)$ - в просторах станів, цілі, ресурсах на моделі для різних класів збурень, визначити на основі розбиття інтервалу стійкі ляпуновські області у фазовому просторі, а за ними-параметри стратегії управління (див. рис. 5).

$$
\left\langle C U S(D A C) \rightarrow \otimes \stackrel{\Pi q}{\longrightarrow}\left\{B^{\prime} C_{i} / i \dot{=}\right\} \rightarrow(C E M)\right\rangle .
$$

Висновок. На підставі системного аналізу та ігрових і когнітивних концепцій розглянуто кризові ситуації, які виникають у техногенних системах з енергоактивними факторами впливу. В основі методу розв'язання конфліктних і кризисних ситуацій, у техногенних системах з ієрархією, покладено методику та обгрунтовано концепції системної гри як технологічних, так й інформаційних підструктур, що узгоджують стратегії розв'язання конфлікту ресурсів. Отже, відбувається адаптація стратегій згідно з цільовими завданнями. При неможливості розв'язання конфлікту формується процедура координації стратегічної та локальної мети спільної для конкуруючих систем, що складає основу методу розв'язання конфлікту.

\section{Перелік літературних джерел}

Akoff, R., \& Emeri, F. (1974). O tceleustremlennykh sistemakh. Moscow: Sov. radio, 272 p. [In Russian].

Barsegian, A. A. (2009). Analiz dannykh i protcessov. St. Petersburg: BKhV-Peterburg, 512 p. [In Russian].

Blinov, A. L., \& Petrov, V. V. (1991). Elementy logiki deistvii. Moscow: Nauka, 232 p. [In Russian].

Boborykin, N. A. (Ed.). (1985). Agregatnye kompleksy tekhnicheskikh sredstv ASU-TP. Leningrad, 271 p. [In Russian].

Bychenok, N. N., Gaiduk, O. V., Mostovoi, V. V., Tereshhenko, V. S., \& Senchenko, A. D. (2000). Prognozno-analiticheskaia sistema podderzhku priniatiia reshenii po regionalnoi bezopasnosti. Upravliaiushie sistemy i mashiny, 4, 88-95. [In Russian].

Chikrii, A. A. (1992). Konfliktno-upravliaemy protcessy. Kyiv: Naukova dumka, 384 p. [In Russian].

Didenko, K. I. (1984). Proektirovanie agregatnykh kompleksov tekhnicheskikh sredstv ASU-TP. Moscow: Energoatomizdat, 168 p. [In Russian].

Dragan, Ya. P., \& Hrytsiuk, Yu. I., \& Palyanitsya, Yu. B. (2016). System analysis of statistical estimation of states of stochastic vibration system and shunt principle. Scientific Bulletin of UNFU, 26(1), 395-402. https://doi.org/10.15421/40260161

Drahan, Ya. P. (1997). Enerhetychna teoriia liniinykh modelei stakhostychnykh syhnaliv. Lviv: TsSD, 361 p. [In Ukrainian]. 
Drahan, Ya. P., Sikora, L. S., \& Yavorskyi, B. I. (2014). Systemnyi analiz stanu ta obgruntuvannia osnov suchasnoi teorii stokhastychnykh syhnaliv: enerhetychna kontseptsiia; matematychnyi substrat; fizychne tlumachennia. Lviv: NVF "Ukrainski tekhnolohii", 240 p. [In Ukrainian].

Draizdel, D. (1990). Vvedenie v dinamiku pozharov. Moscow: Stroiizdat, 424 p. [In Russian].

Druzhinin, G. V., \& Sergeeva, I. V. (1990). Kachestvo informatcii. Moscow: Radio i sviaz, 172 p. [In Russian].

Druzhinin, V. V., \& Kontorov, D. S. (1982). Konfliktnaia radiolokatciia. Moscow: Radio i sviaz, 124 p. [In Russian].

Durniak, B. V., Sikora, L. S., Antonyk, M. S., \& Tkachuk, R. L. (2013a). Kohnityvni modeli formuvannia stratehii operatyvnoho upravlinnia intehrovanymy iierarkhichnymy strukturamy $v$ umovakh ryzykiv i konfliktiv. Lviv: Ukrainska akademiia drukarstva, $449 \mathrm{p}$. [In Ukrainian].

Durniak, B. V., Sikora, L. S., Antonyk, M. S., \& Tkachuk, R. L. (2013b). Avtomatyzovani liudyno-mashynni systemy upravlinnia intehrovanymy iierarkhichnymy orhanizatsiinymy ta vyrobnychymy strukturamy $v$ umovakh ryzyku ta konfliktiv. Lviv: Ukrainska akademiia drukarstva, 514 p. [In Ukrainian].

Durniak, B. V., Sikora, L. S., Lysa, N. K., Tkachuk, R. L., \& Yavorskyi, B. I. (2017). Informatsiini ta lazerni tekhnolohii vidboru potokiv danykh ta yikh kohnityvna interpretatsiia $v$ avtomatyzovanykh systemakh upravlinnia. Lviv: Ukrainska akademiia drukarstva, 644 p. [In Ukrainian].

Gladun, V. P. (1987). Planirovanie reshenii. Kyiv: Nauk. dumka, 168 p. [In Russian].

Grytsiuk, Yu. I., \& Leshkevych, I. F. (2017). The Problems of Definition and Analysis of Software Requirements. Scientific Bulletin of UNFU, 27(4), 148-158. https://doi.org/10.15421/40270433

Hrytsiuk, Yu. I. (2018). Analysis of Software Requirements: Tutorial. Lviv: Publishing House of Lviv Polytechnic, 460 p. Retrieved from: https://192.168.253.4/Research/TrainingAidsEdit.aspx?id=11750. [In Ukrainian].

Hrytsiuk, Yu. I., \& Dalyavskyy, V. S. (2018). Using Petal Diagram for Visualizing the Results of Expert Evaluation of Software Quality. Scientific Bulletin of UNFU, 28(9), 95-104. https://doi.org/10.15421/40280919

Hrytsiuk, Yu. I., \& Zhabych, M. R. (2018). Risk Management of Implementation of Program Projects. Scientific Bulletin of UNFU, 28(1), 150-162. https://doi.org/10.15421/40280130

Karzov, G. P., Margolin, B. Z., \& Shvetcova, V. A. (1993). Fizikomekhanicheskoe modelirovanie protcessov razrusheniia. St. Petersburg: Politekhnika, 391 p. [In Russian].

Kheili, E. Dzh., \& Kumamoto, Kh. (1984). Nadezhnost tekhnicheskikh sistem i otcenka riska. (Realiability engineering and risk assessment). Moscow: Mashinostroenie, 528 p. [In Russian].

Kheis, D. (1981). Prichinnyi analiz $v$ statisticheskikh issledovaniiakh. Moscow: Finansy i statistika, 255 p. [In Russian].

Krapivin, V. F. (1972). Teoretiko-igrovye metody sinteza slozhnykh sistem $v$ konfliktnykh situatciiakh. Moscow: Sov. radio, 192 p. [In Russian].

Kunchenko-Kharchenko, V. T. (2015). Informatsiino-upravlinske dokumentuvannia $v$ iierarkhichnykh systemakh: Kontseptsii zabezpechennia zakhystu informatsii. Lviv: Ukrainska akademiia drukarstva, 376 p. [In Ukrainian].

Marshal, V. (1989). Osnovnye opasnosti khimicheskikh proizvodstv. Moscow: Mir, 671 p. [In Russian].
Medykovskyi, M. D., \& Sikora, L. S. (2002). Avtomatyzatsiia keruvannia enerhoaktyvnymy obiektamy pry obmezhenykh resursakh. Lviv: TsSD, 298 p. [In Ukrainian].

Mekhanizmy. (1972). Mekhanizmy i printcipy tcelenapravlennogo povedeniia. Moscow: Nauka, 295 p. [In Russian].

Mesarovich, M., Mako, D., \& Takakhara, I. (1973). Teoriia ierarkhicheskikh mnogourovnevykh sistem. Moscow: Mir, 344 p. [In Russian].

OKonor, D., \& Makdermat, Y. (2018). Systemne myslennia i poshuk neordynarnykh tvorchykh rishen. Kyiv: Nash format, 240 p. [In Ukrainian].

Palamarchuk, A. M. (1992). Obshhestvenno-territorialnye sistemy: logiko-matematicheskoe modelirovanie. Kyiv: Nauk. dumka, 272 p. [In Russian].

Pavlov, V. V. (1982). Konflikty v tekhnicheskikh sistemakh. Kyiv: Vishha shkola, 184 p. [In Russian].

Perkhach, O. L., \& Podolchak, N. Yu. (2014). Korporatyvni konflikty ta metody yikh podolannia. Lviv: NU "LP", 192 p. [In Ukrainian].

Pospelov, D. A. (1986). Situatcionnoe upravlenie: teoriia i praktika. Moscow: Nauka, 288 p. [In Russian].

Pospelov, D. A. (1989). Modelirovanie rassuzhdenii. Moscow: Radio i sviaz, 184 p. [In Russian].

Roberts, F. S., \& Geiman, A. I. (Ed.). (1986). Diskretnye matematicheskie modeli s prilozheniiami $k$ sotcialnym biologicheskim i ekologicheskim zadacham. Moscow: Nauka, 496 p. [In Russian].

Shapar, A. H., \& Mikheiev, O. V. (2018). Kontseptualni pidkhody do rozuminnia protsesiv antropohennoi destabilizatsii ekolohichnykh system. Visnyk NAN Ukrainy, 3, 56-66. [In Ukrainian].

Sikora, L. (1999). Informatsiino-resursna kontseptsiia identyfikatsii $i$ syntezu robastnykh system upravlinnia. Lviv: TsSD, 372 p. [In Ukrainian].

Sikora, L. S. (1988). Lazerni informatsiino-vymiriuvalni systemy dlia upravlinnia tekhnolohichnymy protsesamy TSS. (Vol. 2). Lviv: Kameniar: TsSD "EBTES", 445 p. [In Ukrainian].

Sikora, L. S. (1998). Systemolohiia pryiniattia rishen ta upravlinnia $v$ skladnykh tekhnolohichnykh strukturakh. Lviv: Kameniar, 453 p. [In Ukrainian].

Sikora, L. S. (2001). Robastni ta informatsiini kontseptsii v protsedurakh syntezu systemy upravlinnia. Lviv, 577 p. [In Ukrainian].

Sikora, L. S., Medykovskyi, M. D., \& Hrytsyk, V. V. (2002). Perspektyvni informatsiini tekhnolohii $v$ systemakh avtomatychnoho upravlinnia enerhoaktyvnymy obiektamy vyrobnychykh struktur. Lviv: DNDI, 416 p. [In Ukrainian].

Smoliakov, E. R. (1986). Ravnovesnye modeli pri nesovpadaiushhikh interesakh uchastnikov. Moscow: Nauka, 221 p. [In Russian].

Sviridov, V. V. (1978). Kontrol v slozhnykh sistemakh. Moscow: Znanie, 61 p. [In Russian].

Timoshenko, S. P. (1967). Kolebaniia v inzhenernom dele. [Vibration Problems in Enginiring]. Moscow: Nauka, 444 p. [In Russian].

Tivilov, T. A. (Ed.). (1988). Dinamika vysokoskorostnogo transporta. [Dynamics of High-speed Vehicles]. Transport, 215 p. [In Russian].

Tkachuk, R. L., \& Sikora, L. S. (2010). Lohiko-kohnityvni modeli formuvannia upravlinskykh rishen intehrovanymy systemamy $v$ ekstremalnykh umovakh. Lviv: Liha-Pres, 404 p. [In Ukrainian].

Vasylenko, V. A. (2017). Heneza, zmist i shliakhy realizatsii kontseptsii mizhnarodnoi ekolohichnoi bezpeky. Visnyk NAN Ukrainy, 7, 89-96. [In Ukrainian].

Volik, B. M. (Ed.). (1985). Metody analiza i sinteza struktur upravliaiushikh sistem. Moscow: Energoatomizdat, 296 p. [In Russian].

Zaitcev, V.S. (1990). Sistemnyi analiz operatorskoi deiatelnosti. Moscow: Radio i sviaz, 120 p. [In Russian].

L. S. Sikora' ${ }^{1}$ N. K. Lysa ${ }^{1}$, R. L. Tkachuk' ${ }^{2}$, B. I. Fedyna ${ }^{3}$, V. I. Kunchenko-Kharchenko ${ }^{4}$

${ }^{I}$ Lviv Polytechnic National University, Lviv, Ukraine

${ }^{2}$ Lviv State University of Life Safety, Lviv, Ukraine

${ }^{3}$ Ukrainian Academy of Printing, Lviv, Ukraine

${ }^{4}$ Cherkasy State Technological University, Cherkasy, Ukraine

\section{INTEGRATION OF GAMING, SYSTEM AND INFORMATION AND RESOURCE CONCEPTS OF ASSESSMENT OF ENERGY ACTIVE INTERACTION OF TECHNOLOGICAL AND ECOLOGICAL SYSTEMS (PART 2)}

Modern accelerated development of man-made industrial structures has led to an increase in the concentration of harmful emissions and their volume in eco-environment (soil, water, atmosphere), the level of pollution of villages, cities, whole regions. Complica- 
tions of technological processes, production growth capacities of thermal power stations, transport, oil and gas industry, in the structure of which includes energy-intensive objects, complicated management processes, which led to a decline in certain levels of security their operation and increased the risks of accidents and disasters. At the same time, the level of risks of accidents and man-made disasters depends on many factors and components of system reliability: reliability and quality of projects of man-made systems, models and algorithms of functioning; quality of constructions, aggregates, components, method of their installation; compliance structures built to the design requirements, methods of Mr. and repairing and testing for input operation; quality of strategies, algorithms for processing data and making managerial decisions; the quality of preparation (engineering, knowledgement, practical etc.) of production and administrative staff, as well as their positive and negative features; preparation of resources for performance of the production process and their quality; the ability to resist resource and informational attacks on man-made system; the ability to withstand informational and mental-psychological attacks on operational and managerial staff when making managerial solutions. Consequently, the causative factors of emergencies are errors in design, limited knowledge of the structure of technological systems and power systems, gaps in the understanding of dynamics information destructive processes that may occur during the operation energy-intensive objects. The game interaction concept (active factors $\leftrightarrow$ technogenic systems) - is the basis for the identification of system, information and energy structure of destruction processes of man-made objects for due to the imposition of unpredictable factors, which due to limitations knowledge of operators can not be taken into account and, accordingly, predicted. All these aspects of risk assessment are both strategic and game-specific character and determine the dynamics of processes in man-made systems, as well the level and nature of the impact on the ecological environment. Based on gaming and system models, as the main principles of analysis the interaction of man-made, ecological and social systems, it is necessary to build general schemes of hierarchical organization of regional society. Solving this problem will allow you to analyze the available resources for production and life of man and society, to assess the risks and probability of conflicts when allocating resources. This approach to resolving the safety of life provides a basis for in-depth analysis the interconnections of a complex of productions with resources and the environment will give the ability to provide a deep recycling of waste. To solve this problem is highlighted, solved and developed the following tasks and methods: the relevance of the problem of risk minimization has been determined and assessed technogenic systems on the ecological environment; the analysis of literary sources in which this problem is considered; the purpose of research and methods of problem solving are formulated; the analysis of causes and factors of emergence of conflict situations both technical and informational; an analysis was conducted and game models of management strategies were constructed; developed a method for conflict resolution in man-made systems; the method of structuring the system and its aggregation is developed; the system game and the way of its representation is considered; the general scheme of interaction of technogenic systems, which generate harmful emissions, with an environmental and social environment like the basis for developing coordination strategies for environmental protection and technology of deep waste processing; new technogenic characteristics and their nature and influence on ecological environment are revealed. So in order to provide a high level of reliability of man-made systems need to consider active, informational in the design process and the cognitive factors affecting the design and implementation of the project taking into account the development of real dynamic situations.

Keywords: System; game; strategy; ecological system; information; managements; decisions; purpose; decision making. 